\title{
The Influence of Informativeness, Information Format and Easy of use in the use of SIAKAD on User Satisfaction (Case Study of Ngudi Waluyo University Students)
}

\author{
Abdul Aziz ${ }^{1}$, Irsal Fauzi ${ }^{2}$, Jaya Ramadaey Bangsa ${ }^{3}$, Setya Indah Isnawati ${ }^{4}$ \\ Ngudi Waluyo Universitas $1,2,3,4$ \\ \{abdulaziz@unw.ac.id ${ }^{1}$,irsalfauzi@unw.ac.id², jayaramadaeybangsa@unw.ac.id ${ }^{3}$, \\ setyaindahisnawati@unw.ac.iid $\left.{ }^{4}\right\}$
}

\begin{abstract}
In its development to meet the needs of students, a web-based academic information system called SIAKAD was created. The SIAKAD program was created to make it easier for students to obtain information related to Ngudi Waluyo University, starting from college registration, value information, and other campus activities. Research conducted at the University of Ngudi Waluyo was conducted to determine the effect of the implementation of the SIAKAD system on student satisfaction. 200 students of the faculty of economics were selected as the population, 66 people who were selected using the Slovin Kumar formula were used as samples in this study. The results of the analysis using multiple regression prove that the informativene, information format and easy of use variables have a positive effect on student satisfaction in SIAKAD users. From the $t$ statistical test, it can be concluded that the hypothesis is accepted. This means that the variables Informativenes, information format and easy of use have a positive influence on student satisfaction in SIAKAD users.
\end{abstract}

Keywords: Informativene; information format and easy of use; satisfaction

\section{Introduction}

The advancement and development of computer technology in today's digital era is increasingly developing and influencing all aspects of human growth. The development of computer technology is in line with the development of existing information systems, without exception the academic information system at Ngudi Waluyo University. Computerized information systems allow users to view reports at any time more quickly and accurately. Presentation of information can be done more easily with the support of information system program packages, which currently have more variations and can be obtained easily in the market (Istianingsih 2009).

To meet the quality needs of information system users, companies or agencies must know who their users are and what they want. In this case, the leaders have actually led to the dimensions of quality. The set of product or service qualities that are determined is what 
leaders believe will best meet the needs of customers or users. User satisfaction of an information system is a factor or measure of success for any development and implementation of an information system in an agency / company. A good service quality image is not based on the point of view or perception of the service provider, but is based on the point of view or perception of the information system user. The user's perception of a system is an overall assessment of the superiority of the system.

Information systems are needed by many parties, both from within the company / agency and from outside the company / agency. Academic information system is a special system for the purposes of managing academic data with the application of computer technology both "hardware" and "software". The increasing public need for formal education, especially higher education, has made higher education a strategic sector which is expected to produce quality human resources. The condition of competition which is quite competitive between tertiary institutions requires educational institutions to pay attention to the quality of education and institutions so that they are able and superior in this competition. Higher education is an institution with one of the tasks it carries out is to provide services to the community to prepare quality and efficient future Human Resources (HR). In the process, universities need information sources that are up to date and always up to date (Handoko, 2011).

research on the satisfaction of using a web-based credit information system. This study found that overall there is a significant difference between expectations and performance. This shows that users of information systems are not satisfied, because user expectations differ greatly from the performance of the credit web system provided to be accessed by users. The five aspects include: reliability, information format, timeliness, informativeness, and easy of use. From the regression analysis, only the variable reliability has a significant effect on user satisfaction. The variable reliability / reliability of the web-based credit information system has a significant effect on the satisfaction of system users, namely residential consumers, in processing payments using web media, it needs to be supported by the reliability of the technology system, so that the smoothness of information related to housing and payments can be accessed easily, and in the end it can be making user satisfaction increase (Fajriyansyah and Edi, 2013).

research on the relationship between the performance of student academic information systems in terms of perceptions of information security on student satisfaction. This study produces a very strong perception that results from the perception of information security variables and the web-based access method variable on student satisfaction variables, while the system application perception variable has a strong effect on the student satisfaction variable (Irawan, 2013).

Ngudi Waluyo University is one of the private universities in Semarang Regency that applies information technology to facilitate access to information needed by students, lecturers and staff. In its development to meet the needs of students, a web-based academic information system called SIAKAD was created. The SIAKAD program was created to make it easier for students to obtain information related to Ngudi Waluyo University, starting from college registration, value information, and other campus activities.

Due to differences in results between previous researchers (research gap), researchers / writers want to re-research by replicating the previous research, namely research was conducted to determine user satisfaction from a system, and compare it with the influence of 5 (five) factors namely informativeness, information format, easy to use, timeliness, and reliability (Fajriansyah and Edi, 2013).

Similarities in research to be carried out with research to determine user satisfaction from a system, and to compare it with the influence of 5 (five) factors, namely informativeness, 
information format, easy to use, timeliness, and reliability. While the differences in research in this study are in different research objects, with different users, in this study (Fajriyansyah and Edi 2013).

This study tries to analyze the satisfaction of UNW students with the academic information system (SIAKAD). The research title that the researcher wants to adopt is: "The Effect of Informativeness, Information Format, and Easy of Use in the Use of SIAKAD on System User Satisfaction (Case Study of Nngudi Waluyo University Students)".

\section{Literature review}

In research, the theoretical basis is like the foundation in a building. A building will look solid if the foundation is strong, as well as writing, without a theoretical basis, the research and methods used will not run smoothly. The theoretical basis needs to be upheld so that the research has a solid foundation, and is not just an act of trial and error (Sugiyono 2012: 52).

\subsection{Academic Information System (SIAKAD)}

Academic Information System (SIAKAD) is an academic information system that is built to provide convenience to users in online campus academic administration activities, such as the New Student Admission process (PMB), making curriculums, making class schedules, filling out Study Plan Cards (KRS), filling in grades, managing lecturer \& student data. This system can also function as a support for data analysis in determining Campus decisions. Ease of Use is defined as the level at which a person believes that computers can be easily understood. On the basis of this definition ease of use of SIAKAD means ease of using a webbased academic information system via the Internet. (Davis et al., 1989: p38)

\subsection{System Quality}

System quality also means the combination of hardware and software in information systems (DeLone and McLean, 1992). an organization or company obtains a system generally in two ways, namely: developing a customized system from scratch through internal system development activities, or buying ready-to-use commercial systems from software vendors either, turnkey systems, backbone systems (backbone system), and vendor-supported system (Hall, 2007).

\subsection{Quality of Information}

Information quality is a characteristic of information in order to meet individual needs when needed. information generation is the process of compiling, organizing, formatting and presenting information to users. Indicators are needed because the quality of information is a variable that cannot be measured directly (Hall, 2007).

\subsection{Actual User}

Actual users are widely used to measure the success of an information system (Seddon, 1997). Actual users are direct users of something that is judged by appropriate behavior to measure the success of an information system implemented by an organization (Seddon and 
Kiew, 1994). This information system user shows the decision to use the information system by the user in completing user tasks (Davis, 1989).

\subsection{Ease of Use}

Ease of use is defined as individual belief where if they use a certain system it will be free from effort (Mathieson, 1991). So if someone believes that a technology is easy to use, that person will use it. So that this convenience variable gives an indication that a system is not made to make it difficult for the user, but instead a system is made with the aim of making it easy for the user. Thus, someone who uses a certain system will work easier when compared to someone who works manually. Several previous studies that prove that the perception of Ease of Use has an influence on attitudes to using technology, including research conducted by Ramadhani (2008). The intensity of use and interaction between the user and the system can also indicate ease of use. A system that is frequently used shows that the system is better known, and easier to use by its users. Ease of use reduces users' efforts in learning the origins of system usage behavior. Ease of use also gives an indication that information system users can work more easily than those without using information systems. (Davis. Et al., 1989: p40).

\subsection{User Satisfaction}

User satisfaction is things that include assessments including the experience of system users when using the information system which will have a potential impact on the information system itself (Seddon and Kiew, 1994). User satisfaction is a clean feeling of pleasure or displeasure in receiving information systems from the overall benefits that someone expects, where these feelings are generated from interactions with information systems.

Satisfaction is a feeling of pleasure or disappointment for someone who arises after comparing perceptions or impressions of the performance or results of a product and its expectations (Kotler 2003). So, satisfaction is a function of perceptions or impressions of performance and expectations. If the performance is below expectations, the customer is not satisfied. If the performance meets expectations, the customer will be satisfied. If the performance exceeds expectations, the customer will be very satisfied or happy.

\section{Method}

This research is a quantitative research. Sources of research data using primary data, namely questionnaires distributed to respondents. The data collection technique used in this research is by distributing questionnaires directly to selected respondents. The sampling technique used purposive random sampling with data analysis using statistical software SPSS Version 19 as a tool in analyzing and processing data. The population in this study were all students in the faculty of economics as many as 200 people. The sample was obtained as many as 66 respondents with the consideration of sampling in this study using the Slovin formula (Djarwanto, PS, 2002).

\section{Results and Discussion}




\subsection{Result}

Tabel 1. Multiple Regression Analysis Results

Coefficients $^{\mathbf{a}}$

\begin{tabular}{ccccc}
\hline \multirow{2}{*}{ Model } & \multicolumn{2}{c}{ Unstandardized Coefficients } & Standardized Coefficients \\
\cline { 2 - 4 } & B & Std. Error & Beta \\
\hline & (Constant) & 1,775 & 0,836 & \\
1 & Informativeness & 0,455 & 0,083 & 0,502 \\
Information Format & 0,221 & 0,074 & 0,246 \\
& easy of use & 0,192 & 0,059 & 0,262 \\
\hline
\end{tabular}

a. Dependent Variable: student satisfaction in SIAKAD users

Source: Primary data processed, 2021

Tabel 2. F Test Results

ANOVA $^{b}$

\begin{tabular}{ccccccc}
\hline & Model & Sum of Squares & df & Mean Square & F & Sig. \\
\hline & Regression & 321,125 & 3 & 107,042 & 56,659 & $0,000^{\mathrm{a}}$ \\
1 & Residual & 117,133 & 62 & 1,889 & & \\
& Total & 438,258 & 65 & & & \\
\hline
\end{tabular}

a. Predictors: (Constant), Ease of Use (easy of use), Information Format, Informativeness

b. Dependent Variable: student satisfaction in SIAKAD users

Source: Primary data processed, 2021

Tabel 3. Result of Determination Coefficient Test (R2)

Model Summary ${ }^{\mathbf{b}}$

\begin{tabular}{lllll}
\hline Model & R & R Square & Adjusted R Square & Std. Error of the Estimate
\end{tabular}

$10,856^{\mathrm{a}} \quad 0,733 \quad 0,720 \quad 1,374$

a. Predictors: (Constant), Ease of Use (easy of use), Information Format, Informativeness

b. Dependent Variable: student satisfaction in SIAKAD users

Source: Primary data processed, 2021

Tabel 4. $\mathrm{T}$ test results

Coefficients $^{\mathrm{a}}$

\begin{tabular}{ccccccc}
\hline \multirow{2}{*}{ Model } & \multicolumn{2}{c}{ Unstandardized Coefficients } & Standardized Coefficients & & \multirow{2}{*}{ Sig. } \\
\cline { 2 - 5 } & B & Std. Error & Beta & & \\
\cline { 2 - 5 } & (Constant) & 1,775 & 0,836 & & 2,123 & 0,038 \\
& Informativeness & 0,455 & 0,083 & 0,502 & 5,510 & 0,000 \\
Information Format & 0,221 & 0,074 & 0,246 & 2,976 & 0,004 \\
& easy of use & 0,192 & 0,059 & 0,262 & 3,271 & 0,002 \\
\hline
\end{tabular}

a. Dependent Variable: student satisfaction in SIAKAD users

Source: Primary data processed, 2021

\subsection{Discussion}

\section{a) The Influence of Informativeness on Student Satisfaction in SIAKAD Users}

From the results of the processed data, it was found that the results of Informativenes on student satisfaction in SIAKAD users obtained significant results, namely less than 0.05 (p 
$<0.05$ ) and were valid. Informativeness on student satisfaction in SIAKAD users shows a positive direction. This condition shows that Informativenes has a positive and significant effect on student satisfaction in SIAKAD users. So the higher the informativenes, the higher the student satisfaction in SIAKAD users.

\section{b) The Influence of Information Format on Student Satisfaction in SIAKAD Users}

From the results of the processed data, it was found that the results of the information format on student satisfaction in SIAKAD users obtained significant results, namely less than $0.05(\mathrm{p}<0.05)$ and were valid. information format on the satisfaction of accounting students in SIAKAD users shows a positive direction. This condition indicates that the information format has a positive and significant effect on the satisfaction of accounting students in SIAKAD users. So the more the information format, the higher the satisfaction of accounting students in SIAKAD users.

\section{c) Effect of Ease of Use (easy of use) on Student Satisfaction in SIAKAD Users}

From the results of the processed data, it was found that the results of the ease of use (easy of use) on the satisfaction of accounting students in SIAKAD users obtained significant results, namely less than $0.05(\mathrm{p}<0.05)$ and were valid. ease of use (easy of use) on the satisfaction of accounting students in SIAKAD users shows a positive direction. This condition indicates that the ease of use (easy of use) has a positive and significant effect on the satisfaction of accounting students in SIAKAD users. So the higher the ease of use (easy of use), the higher the satisfaction of accounting students in SIAKAD users.

\section{Conclusions and Suggestions}

\subsection{Conclusion}

Based on the results of hypothesis testing in this study, it shows that the Informativene variable, information format and easy of use have a positive effect on student satisfaction in SIAKAD users. From the t statistical test, it can be concluded that the hypothesis is accepted. This means that the variables Informativenes, information format and easy of use have a positive influence on student satisfaction in SIAKAD users. The value of the coefficient of determination shows an Adjusted R2 value of 0.720.This means that the dependent variable, namely student satisfaction in SIAKAD users, can be explained by independent variables consisting of reliability, informativenes, information format, ease of use ( easy of use) of $72 \%$ while the remaining $28 \%$ is influenced by other factors outside the variables studied in the regression model.

\subsection{Suggestion}

Informativeness, information format, and easy of use need to be maintained and even improved in order to increase student satisfaction with SIAKAD users. Student satisfaction of SIAKAD users is important for an institution because if students are satisfied, students will be enthusiastic in learning. 


\section{Reference}

[1] Anastasia, Njo. 2000. Analisa Inventasi dalam Pengambilan Keputusan Inventasi pada Pembangunan Lapangan Golf dan Perumahan Citraraya. Tesis, Magister Teknik, Program Pasca Sarjana, Universitas Kristen Petra. Surabaya.

[2] Bovee, C.L dan John V. Thill, 1995, Business Communication Today, Fourth Edition, United States of America: Mc Graw Hill. Inc.

[3] Dipohusodo, Istimawan, 1996, Manajemen Proyek dan Konstruksi, Jilid 1, Kanisius, Yogyakarta

[4] Engel, 1990. Jurnal Ilmiah Manajemen \& Bisnis. 2001. Menuju Kepuasan Pelanggan Melalui Penciptaan Kualitas Pelayanan. Sumatera Utara.

[5] Fandy Tjiptono, 2005. Pemasaran Jasa, Bayumedia Publishing, Malang

[6] Feigenbaum, Armand V., 1991, Total Quality Control. Third Edition, McGraw-Hill, Inc. 1991.

[7] Gasperz, 1997. Jurnal Ilmiah Manajemen \& Bisnis. 2001. Menuju Kepuasan Pelanggan Melalui Penciptaan Kualitas Pelayanan. Sumatera Utara.

[8] Ghozali, Imam. 2011. Aplikasi Analisis Multivariat dengan IBM SPSS. Semarang : BP Undip.

[9] Husni, Ali. 2004. Analisis Kualitas Perumahan Nasional Ditinjau dari Persyaratan dan Kepuasan Pelanggan. Tesis Magister Teknik Sipil, Universitas Atmajaya. Yogyakarta.

[10] Kolarik, William J., 1995, Creating Quality Concepts, Systems, Strategies, and Tools, McGraw-Hill, Inc. Intemational Edition

[11] Kotler, Philip., 2002. Dasar-dasar Pemasaran. Jilid 1, Alih Bahasa Alexander Sindoro dan Benyamin Molan, Penerbit Prenhalindo, Jakarta

[12] Kwanda, Timoticin, dkk. 2003. Analisis Kepuasan Penghuni Rumah Sederhana Tipe 36 di Kawasan Sidoarjo Berdasarkan Faktor Kualitas Banguan, Lokasi, Desain, Sarana dan Prasarana. Jurusan Arsitektur, Universitas Kristen Petra. Surabaya.

[13] Lovelock, Christopher H, dan Wright Lauren K., 1999, Principles of service marketing and management, Prentice-Hall.inc, A Simon and Schster Company,New JerseY

[14] Lovelock, C.H., 1988. Managing Service. New Jersey: Prentice Hall.

[15] Mulyono, 2008. Analisis Pengaruh Kualitas Produk dan Kualitas Layanan Terhadap Kepuasan Konsumen, Tesis. Magister Manajemen, Universitas Diponegoro, Semarang

[16] Nasution. 2004. Metode Research, Jakarta : Bumi Aksara.

[17] Parasuraman, A, V.A. Zeithami and L.L. Berry, 1988, “A Multiple-Item Scale for Measuring Consumer Perceptions of Service Quality”, Journal of Retailling, Vol. 64, p. $12-40$

[18] Rangkuti, Freddy. 2009. Measuring Customer Satisfaction : Teknik Mengukur dan Strategi Meningkatkan Kepuasan Pelanggan, Jakarta : PT. Gramedia Pustaka Utama.

[19] Rentiasih, Ketut Asrini Budi. 2004. Analisis Faktor-faktor yang Dipertimbangkan Konsumen dalam Memilih Lokasi Perumahan Menengah di Denpasar dan Kabupaten Badung Bali. Tesis, Magister Teknik, Program Pasca Sarjana, Universitas Kristen Petra. Surabaya.

[20] Sanyoto, T. 2006. Analisis Kepuasan Konsumen Perumahan Sederhana Berdasarkan Lokasi, Sarana dan Prasarana Fisik Bangunan, dan Harga Rumah di Kota Mataram. Tesis, Magister Teknik Sipil, Universitas Islam Sultan Agung. Semarang.

[21] Schnaars, S.P., 1991. Marketing Strategy : A Customer-Driven Approach. The Free Press, New York. 
[22] elasih. (2004). Uji Kesenjangan menggunakan diagram kartesius. www.hardipurba.com

[23] Sugiarto, Dergibson S., Lasmono SO. 2001. Teknik Sampling. PT Gramedia Pustaka Utama. Jakarta.

[24] Sugiono dan Eri Wibowo. 2004. Statistik untuk Penelitian dan Aplkasinya dengan 10.0 For Windows. Alfabeta. Bandung

[25] Sugiyono. 2009. Metode Penelitian Kuantitatif, Kualitatif, R \& D. Bandung: Alfabeta.

[26] T. Kuswartojo, Suparti A.S. 1997. Perumahan dan Permukiman yang Berwawasan Lingkungan. PP- PSL, Jakarta

[27] Tjiptono. F. and Gregorius Chandra. 2007. Service, Quality Satisfaction. Andi Ofset. Yogyakarta.

[28] Tjiptono. F. 1997. Prinsip-prinsip Total Quality Service, Penerbit Andi Yogyakarta

[29] Valerie A. Zeithaml, Parasuraman, A., dan Leonard L. Berry, 1993. Delivering Quality Service: Balancing Customer Perceptions and Expectations, Free Press, New York

[30] Widiana, M.Erma. 2009. Analisis Faktor-faktor yang Memperngaruhi Keputusan Konsumen dalam Membeli Rumah (Studi Kasus Perumahan Viharta PT. MBP Gresik. Majalah Ekonomi Tahun XIX No. 3. Surabaya.

[31] Yazid, 2001. Pemasaran Jasa-Konsep dan Implementasi. Yogyakarta : Ekonisia. 